\title{
VYUŽITIE UAV TECHNOLÓGIE PRE KLASIFIKÁCIU A MAPOVANIE KRAJINY VO FLUVIÁLNEJ GEOMORFOLÓGII
}

\author{
Miloš Rusnák*, Ján Sládek***, Anna Kidová* \\ * Geografický ústav SAV, Štefánikova 49, 81473 Bratislava, \\ ** GEOTECH Bratislava, s. r. o., Černyševského 26, 85101 Bratislava, \\ geogmilo@savba.sk,geogslad@savba.sk,geogkido@savba.sk
}

\begin{abstract}
Using UAV technology for landscape classification and mapping in fluvial geomorphology

The aim of this paper is to present the possibilities of UAVs (Unmanned Aerial Vehicles) as photogrammetry payload carriers for data acquisition and fluvial landform identification and mapping. The manual and automatic classification of the Belá River riparian zone for landscape object identification and the analyses of the point cloud density after vegetation filtration was performed. The HEXAKOPTER XL including the Sony NEX 6 camera with $16-50 \mathrm{~mm}$ lens for landscape monitoring features was used. Data was processed in Agisoft PhotoScan software. The RMSE (root mean square error) of aligned images was $60.121 \mathrm{~mm}$ (x coordinate), 43.7584 $\mathrm{mm}$ (y coordinate) and $29.46 \mathrm{~mm}$ ( $\mathrm{z}$ coordinate). The resulting point cloud was semiautomatic classified in the software Terrasolid - Terrascan (Microstation), in the following six classes: high vegetation (over $5 \mathrm{~m}$ ), medium vegetation (from $1.5 \mathrm{~m}$ to 5 $\mathrm{m}$ ), small vegetation (from $0.2 \mathrm{~m}$ to $1.5 \mathrm{~m}$ ), topographic surface and water surface. Orthophotomosaic was classified in ArcGIS software by supervised Maximum Likelihood Classification (MLC). Here training site signatures identified the five land cover categories (water area, bar surface, vegetation, Large Woody Debris - LWD and bare surface). The classification of photogrammetric derived point clouds increases the accuracy elevation model, but on the other hand, does not capture the real terrain and topography under the vegetation.
\end{abstract}

Key words: UAV, point cloud classification, 3D modelling, vegetation separation, topography surface, Belá river

\section{ÚVOD}

Fluviálna geomorfológia predstavuje vel'mi dynamickú a vo svete rozvinutú výskumnú oblast' geomorfológie. Geomorfológia, ako vedná disciplína, sa postupne mení z opisne chápanej na procesne orientovanú vedu, ktorá zdôrazňuje nové a moderné geomorfologické koncepty, ako aj používanie kvantitatívnych metód a spôsobov priestorového zberu dát (Jain et al. 2012, Gallay et al. 2015 a Gallay et al. 2016b). Nevyhnutným predpokladom pre procesne orientované chápanie krajiny je získavanie presných modelov a dát s vysokým rozlíšením (James a Robson 2012 a Westoby et al. 2012). Turner et al. (2015) definujú pät' spôsobov tvorby digitálneho modelu v geovednom výskume: 1) pozemné meranie pomocou globálnych navigačných satelitných systémov, 2) tachymetria, 3) pozemné laserové skenovanie, 4) letecké laserové skenovanie a 5) UAV fotogrametriu (UAV - Unmanned Aerial Vehicle). Na rozdiel od iných metód má UAV fotogrametria z hladiska mapovania dynamických procesov viacero predností. Jej hlavné výhody spočívajú predovšetkým v rýchlom, presnom a bezkontaktnom spôsobe mapovania, pričom meranie je možné realizovat' operatívne (Turner et al. 2015). 
$\mathrm{Na}$ Slovensku sa v oblasti fluviálnej geomorfológie doposial' aplikovali predovšetkým metódy, ktoré sa viažu na analýzy spojené s terénnym prieskumom (analýza priečnych profilov, pozdĺžneho profilu, hierarchickej klasifikácie morfológie riek, hydromorfologický prieskum, analýza sedimentov - napr. Lehotský a Lacika 2007, Medved'ová et al. 2007, Tomčíková 2007, Anstead a Barabas 2013 a Frandofer a Lehotský 2013) a dištančné metódy založené na získavaní priestorových údajov z historických máp (Pišút 1995, 2002, 2006 a 2008 a Pišút a Tomčíková 2008) a leteckých snímok (Novotný et al. 2007, Frandofer a Lehotský 2014, Rusnák a Lehotský 2014, Kidová et al. 2016, Rusnák et al. 2016b a Novotný a Cebecauerová 2016).

UAV technológie predstavujú finančne dostupné a efektívne mobilné mapovacie zariadenia (Westoby et al. 2012, Fonstad et al. 2013 a Szabó et al. 2017), ktoré premost’ujú detailné terénne výskumy s klasickým leteckým snímkovaním (Neitzel a Klonowski 2011, Kelcey a Lucieer 2012 a Sládek a Rusnák 2013). V súčasnosti sa pri procese spracovania obrazových dát získaných pomocou UAV najčastejšie využíva štandardizovaný proces založený na metóde Structure from Motion (SfM) pre tvorbu 3D povrchov (Westoby et al. 2012 a Fonstad et al. 2013). Na rozdiel od klasickej fotogrametrie využívajúcej systém kontrolných bodov (GCP) na výpočet známej pozície kamery a jej orientácie, SfM pomocou algoritmu vyhl'adáva identické body na snímkach zosnímaných z rozličných uhlov. Výhodou algoritmu je vyššia miera automatizácie a l'ahšieho použitia, čo umožňuje jeho aplikáciu vo viacerých komerčných a vol'ne dostupných programoch na spracovanie 3D modelov. $\mathrm{Na}$ Slovensku a v Česku sa použitie bezpilotných technológií rozvíja predovšetkým v posledných rokoch (tab. 1). Ucelený prehl'ad o rozdelení a využití UAV v geografii opisujú vo svojej práci Sládek a Rusnák (2013), podobne ako v Česku Miřijovský et al. (2012), ktorí približujú využitie bezpilotných systémov pre zber dát. Miřijovský (2013) komplexne opisuje následný proces spracovania snímok pomocou UAV fotogrametrie. Priekopníkmi vo využívaní UAV pre vedecké účely na Slovensku a v Česku boli Plánka (1984 a 1987), Plánka et al. (1983), Kolejka (1987), Kolejka a Petch (1989) a Hanzl a Plánka (1992), ktorí na analýzu zmien krajiny využívali dial'kovo ovládaný model Rogallo s upravenou kamerou Flexaret. Prehl'ad počiatkov snímkovania krajiny pomocou RC modelov prináša Plánka (2014), ktorý uvádza prvé pokusy okolo roku 1965 pod vedením O. Stehlíka, na vtedajšom Geografickom ústave CSAV v Brne. Müllerová et al. (2016 a 2017) využívajú snímky z UAV s vysokým rozlíšením a infračerveným spektrom na identifikáciu a monitoring inváznych taxónov v stredných Čechách. Pacina a Holá (2014) použili UAV a KAP (kite aerial photography) na identifikáciu zaniknutých sídel v českom pohraničí. Kršlák et al. (2016) a Blišt’an et al. (2016b) poukazujú na využitie UAV pri tvorbe digitálnych modelov t'ažobných lomov (množstvo odt’aženého materiálu) a odkryvov. Stuchlík et al. (2015) využili tvorbu digitálnych modelov a snímkovanie pomocou termálnej kamery v polárnych oblastiach Svalbardu. Presnost' fotogrametricky derivovaného mračna bodov z UAV pri výskume lesnej pokrývky hodnotí Tomaštik et al. (2017) a Mikita et al. (2016) využíva metódy UAV fotogrametrie na detegovanie drevnej hmoty.

Vo svetovej literatúre sa v oblasti fluviálnej geomorfológie UAV technológie využívajú na získavanie presných digitálnych modelov nivy, monitoring ripariálneho lesa a identifikáciu zmien pôdorysnej vzorky a laterálneho pohybu (Dunford et al. 2009, Vericat et al. 2009, Hervouet et al. 2011 a Tamminga et al. 2015) alebo 
optickej batymetrie (Lejot et al. 2007 a Flener et al. 2013). Na Slovensku sa UAV fotogrametria vo fluviálnej geomorfológii uplatnila pri výskume avulzného koryta na rieke Ondava (Sládek a Rusnák 2013). Viacero výskumov s aplikáciou UAV fotogrametrie nájdeme v Česku (pozri tab. 1), kde sa využila pri výskume riečneho meandra a brehovej erózie na rieke Morava (Miřijovský a Vavra 2012), pri analýze vývoja Kenického meandra rieky Moravy v CHKO Litovelské Pomoraví - Miřijovský et al. (2015), alebo v povodí hornej Vydry v pohorí Šumava (Miřijovský a Langhammer 2015 a Langhammer et al. 2017).

Tab. 1.Prehl’ad prác autorov zo Slovenska a Česka, ktoré využívali UAV technológie na mapovanie a tvorbu digitálnych modelov krajiny

\begin{tabular}{|c|c|c|c|c|c|}
\hline Oblast' výskumu & Lokalita & Typ nosiča & Kamera & Autori & Poznámka \\
\hline \multirow{2}{*}{$\begin{array}{l}\text { Metodika zberu } \\
\text { dát }\end{array}$} & \multirow[t]{2}{*}{ Senica na Hané } & paraglide PIXY & \multirow[t]{2}{*}{ Canon EOS 500D } & $\begin{array}{l}\text { Miřijovský et al. } \\
(2012)\end{array}$ & $\begin{array}{l}\text { ortofotomozaika s presnost'ou } \\
0,062 \mathrm{~m}(\mathrm{x}, \mathrm{y})\end{array}$ \\
\hline & & $\begin{array}{l}\text { paraglide PIXY/ } \\
\text { hexakopter }\end{array}$ & & Miřijovský (2013) & $\begin{array}{l}\text { komplexná metodika zberu dát } \\
\text { pomocou UAV }\end{array}$ \\
\hline \multirow{3}{*}{$\begin{array}{l}\text { Mapovanie } \\
\text { krajiny }\end{array}$} & priehrada Nové Mlýny & rogalo & Flexaret & $\begin{array}{l}\text { Plánka }(1984,1987) ; \\
\text { Plánka et al. (1983); } \\
\text { Kolejka (1987); } \\
\text { Kolejka a Petch } \\
\text { (1989); Hanzl a } \\
\text { Plánka (1992) }\end{array}$ & $\begin{array}{l}\text { prvé práce využivajúce bezpilotný } \\
\text { prostriedok pre snímkovanie krajiny }\end{array}$ \\
\hline & $\begin{array}{l}\text { priehrada Nechranice, } \\
\text { povrchová t’ažba v } \\
\text { oblasti mesta Most }\end{array}$ & malé lietadlo & Nikon D3X & $\begin{array}{l}\text { Pacina a Sládek } \\
(2015)\end{array}$ & \\
\hline & letisko Lucerne & Scout B1-100 & $\begin{array}{l}\text { laser skener Riegle } \\
\text { VUX-1/Sony } \\
\text { A6000/ hyperspek- } \\
\text { trálna kamera } \\
\text { AISA KESTREL } \\
10\end{array}$ & Gallay et al. (2016a) & $\begin{array}{l}\text { snímkovanie s rozlíšením } 0,1 \mathrm{~m} \\
\text { a presnostou } 0,02 \mathrm{~m} \text {, hustota lidaro- } \\
\text { vého mračna bodov } 1111 \text { bodov } / \mathrm{m}^{2}\end{array}$ \\
\hline \multirow{3}{*}{$\begin{array}{l}\text { Mapovanie } \\
\text { lomov, odkryvov } \\
\text { a tažobných } \\
\text { oblastí }\end{array}$} & baňa Bankov (Košice) & DJI Phantom 2 & DJI HD camera & $\begin{array}{l}\text { Blišt’anová et al. } \\
(2015,2016)\end{array}$ & mapovanie objektov a ich ochrana \\
\hline & $\begin{array}{l}\text { povrchový lom } \\
\text { (Jastrabá) }\end{array}$ & $\begin{array}{l}\text { DJI Phantom } 2 \\
\text { Vision+ }\end{array}$ & FC200 camera & $\begin{array}{l}\text { Kršlák et al. (2016) } \\
\text { Blištan et al. (2016a) }\end{array}$ & $\begin{array}{l}\text { point cloud s rozlišením } 0,0403 \mathrm{~m} / \\
\text { pixel a ŘMSE kontrolných bodov } \\
0,0479 \mathrm{~m}\end{array}$ \\
\hline & $\begin{array}{l}\text { dokumentácia } \\
\text { geologického odkryvu } \\
\text { (Lehôtka pod Brehmi) }\end{array}$ & $\begin{array}{l}\text { DJI Phantom } 2 \\
\text { Vision+ }\end{array}$ & FC200 camera & Blišt'an et al. (2016b) & $\begin{array}{l}\text { tvorba 3D modelu s rozlíšením } \\
0,01 \mathrm{~m} / \text { pixel }\end{array}$ \\
\hline $\begin{array}{l}\text { Mapovanie } \\
\text { vegetácie }\end{array}$ & $\begin{array}{l}\begin{array}{l}\text { centrálna čast' Českej } \\
\text { republiky }\end{array} \\
\end{array}$ & krídlo & $\begin{array}{l}\text { Canon S100/ Sony } \\
\text { A5100 }\end{array}$ & $\begin{array}{l}\text { Müllerová et al. } \\
(2016,2017)\end{array}$ & $\begin{array}{l}\text { využitie VIS a NIR snímok pre } \\
\text { identifikáciu Agátu bieleho }\end{array}$ \\
\hline \multirow[t]{2}{*}{ Výskum lesa } & $\begin{array}{l}\text { Kremnica, Vysoké } \\
\text { Tatry, Modrý Kameň }\end{array}$ & DJI Phantom 3 & DJI camera & Tomaštik et al. (2017) & $\begin{array}{l}\text { hodnotenie presnosti mračna bodov } \\
\text { a vplyvu/rozmiestnenia množstva } \\
\text { GCP na kvalitu modelu }\end{array}$ \\
\hline & Mariabrunn & $\begin{array}{l}\text { DJI S800 Spreading } \\
\text { Wings }\end{array}$ & Sony NEX 5R & Mikita et al. (2016) & detekcia drevnej hmoty \\
\hline \multirow{3}{*}{$\begin{array}{l}\text { Zaniknuté } \\
\text { osídlenie } \\
\text { a pamiatky }\end{array}$} & $\begin{array}{l}\text { česko-nemecké } \\
\text { pohraničie (Jilmová) }\end{array}$ & Kite/oktokopter & $\begin{array}{l}\text { Canon PowerShot } \\
\text { D10/termálna } \\
\text { kamera Optris PI }\end{array}$ & $\begin{array}{l}\text { Pacina a Holá (2014); } \\
\text { Brüna et al. (2014) }\end{array}$ & ortofoto s rozlíšením $0,015 \mathrm{~m}$ \\
\hline & Sudán (Sabaloka) & Kite & $\begin{array}{l}\text { Canon PowerShot } \\
\text { D10 }\end{array}$ & Pacina (2015) & DSM model s presnost'ou $0,05 \mathrm{~m}$ \\
\hline & priehrada Fláje & malé lietadlo & Nikon D810 & Pacina et al. (2016) & $\begin{array}{l}\text { rozlíšenie DSM: } 0,05-0,56 \mathrm{~m} \text { a } \\
\text { ortofoto: } 0,027-0,141 \mathrm{~m}\end{array}$ \\
\hline Zosuvy & obec Sv. Anton & Hexakopter XL & Sony NEX 6 & Rusnák et al. (2016a) & $\begin{array}{l}\text { vertikálna chyba DSM } 0.425 \mathrm{~m} \\
\text { a DTM } 0.337 \mathrm{~m}\end{array}$ \\
\hline Arktické oblasti & Svalbard & Hexakopter XL & $\begin{array}{l}\text { GoPro HD Hero 3/ } \\
\text { termálna kamera } \\
\text { Optris PI }\end{array}$ & Stuchlík et al. (2015) & RMSE chyba $0,4 \mathrm{~m}$ \\
\hline \multirow{6}{*}{$\begin{array}{l}\text { Fluviálna } \\
\text { geomorfológia }\end{array}$} & rieka Ondava & Hexakopter XL & Nikon D90 & $\begin{array}{l}\text { Sládek a Rusnák } \\
\text { (2013) }\end{array}$ & ortofoto $\mathrm{s}$ rozlíšením $0,02 \mathrm{~m}$ \\
\hline & rieka Belá & Hexakopter XL & Sony NEX6 & Rusnák et al. (2018) & DSM a ortofoto s presnost'ou $0,05 \mathrm{~m}$ \\
\hline & $\begin{array}{l}\text { rieka Morava } \\
\text { (Litovelské Pomoraví) }\end{array}$ & paraglide PIXY & Canon EOS 500D & $\begin{array}{l}\text { Miřijovský a Vavra } \\
\text { (2012); Svobodová } \\
\text { et al. (2012) }\end{array}$ & $\begin{array}{l}\text { RMSE } 0,021 \text { m (horizontálna) } \\
\text { a } 0,023 \text { m (vertikálna) }\end{array}$ \\
\hline & $\begin{array}{l}\text { rieka Morava } \\
\text { (Kenický meander) }\end{array}$ & Hexakopter XL & Canon EOS 500D & $\begin{array}{l}\text { Miřijovský et al. } \\
\text { (2015) }\end{array}$ & vertikálna RMSE 0,093 m \\
\hline & potok Javoří (Šumava) & Hexakopter XL & Canon EOS 500D & $\begin{array}{l}\text { Langhammer et al. } \\
\text { (2017) }\end{array}$ & $\begin{array}{l}\text { využitie UAV pre optickú } \\
\text { granulometriu }\end{array}$ \\
\hline & potok Javoří (Šumava) & hexakopter & Canon EOS 500D & $\begin{array}{l}\text { Miřijovský a Lan- } \\
\text { ghammer (2015) }\end{array}$ & $\begin{array}{l}4 \text { časové rorizonty s vertikálnou } \\
\text { RMSE } 0,020-0,037 \mathrm{~m}\end{array}$ \\
\hline
\end{tabular}


Ciel'om predkladaného príspevku je mapovanie riečnej krajiny v povodí rieky Belej a zhodnotenie použitia UAV ako nosiča obrazových snímačov na identifikovanie fluviálnych foriem a vegetácie pomocou manuálnej a automatickej klasifikácie UAV ortofotosnímok. Dôraz sa kladie na klasifikáciu a analýzu hustoty mračna bodov v jednotlivých fluviálnych formách. Dalej si všíma vplyv jednotlivých tried krajinnej pokrývky na tvorbu digitálneho modelu zemského povrchu použitel'ného vo fluviálno-geomorfologickom výskume.

\section{PROCES SPRACOVANIA SNÍMOK ZÍSKANÝCH POMOCOU UAV}

Rozšírenie bezpilotných systémov pri mapovaní krajiny je úzko zviazané s rozvojom techník počítačovej vizualizácie algoritmu SfM (Structure from Motion), ktorý bol vyvinutý v 70. rokoch minulého storočia (Ulman 1979) a neskôr využitý aj v oblasti fotogrametrie ako SfM-MVS - Structure-From-Motion Multi-View Stereo Photogrammetry (Harwin a Lucieer 2012 a Dietrich 2016). Algoritmus využíva, podobne ako klasická fotogrametria, prekrývanie snímok (fotografií) na identifikáciu identických objektov z viacerých uhlov, pričom prvky vnútornej a vonkajšej orientácie vypočítava automaticky bez zadávania preddefinovaných a zameraných kontrolných bodov (GCP); (Micheletti et al. 2015). Kombinácia fotogrametrie a počítačovej vizualizácie pre spracovanie UAV dát a tvorbu georeferencovaného mračna bodov sa v súčasnosti označuje ako UAV-MVS metóda (Harwin a Lucieer 2012). Pre tvorbu 3D geometrie sa skúmaný objekt nasníma z rôznych uhlov a algoritmus vypočíta pozíciu kamery, orientáciu a 3D koordináty modelu. V súčasnosti sa najčastejšie na identifikáciu spoločných objektov (keypoints) v celom súbore snímok využíva algoritmus SIFT (Scale Invariant Feature Transform). Následne sa medzi jednotlivými bodmi vypočítajú priestorové vzt’ahy. V druhom kroku získané parametre (orientácia kamery a fotografií) vstupujú do algoritmov (ako je SGM - Semi-Global Matching) pre generovanie hustého mračna bodov (dense point cloud), ktoré prebieha automaticky, na rozdiel od klasického generovania 3D modelov na základe stereo dvojice snímok (stereomatching). Výsledkom je vyššia miera automatizácie a l'ahšieho použitia, pričom pre tvorbu modelu nie je nutné explicitné definovanie vnútornej a vonkajšej orientácie (Fonstad et al. 2013). Algoritmus využívajú viaceré softvérové riešenia, ktoré prinášajú intuitívnejšie a automatizované alebo poloautomatizované ovládanie a sú založené na komerčnej (Agisoft PhotoScanTM, Pix4DTM) alebo vol'ne šíritel'nej licencii pre nekomerčné použitie (ARC3DTM, BundlerTM, MicrosoftC PhotosynthTM); (Sládek a Rusnák 2013).

\section{ŠTUDOVANÉ ÚZEMIE}

Na aplikáciu UAV fotogrametrie bol vybraný riečny úsek vodného toku Belá v jej dolnej časti (obr. 1). Rieka Belá vzniká sútokom Tichého a Kôprovského potoka vo Vysokých Tatrách a po sútok s Váhom dosahuje dížku 23,6 km. Povodie je značne asymetrické s prevládajúcimi pravostrannými prítokmi. Plocha povodia má $244 \mathrm{~km}^{2} \mathrm{~s}$ maximálnou nadmorskou výškou $2494 \mathrm{~m} \mathrm{n}$. m. a minimom vo výške $630 \mathrm{~m} \mathrm{n}$. m. Nalietané územie malo tvar obdížnika v dížke $1,6 \mathrm{~km}$ a šírke $250-$ $300 \mathrm{~m}$. Na hodnotenie presnosti bol zvolený výsek modelového územia s rozmermi $210 \times 260$ m zahŕňajúci riečny úsek s vrcholovou lavicou a nárazovým svahom, ktorý eroduje tridsat' metrov vysokú terasu. Skúmané územie má charakter divočiaco-migrujúceho vodného toku. 

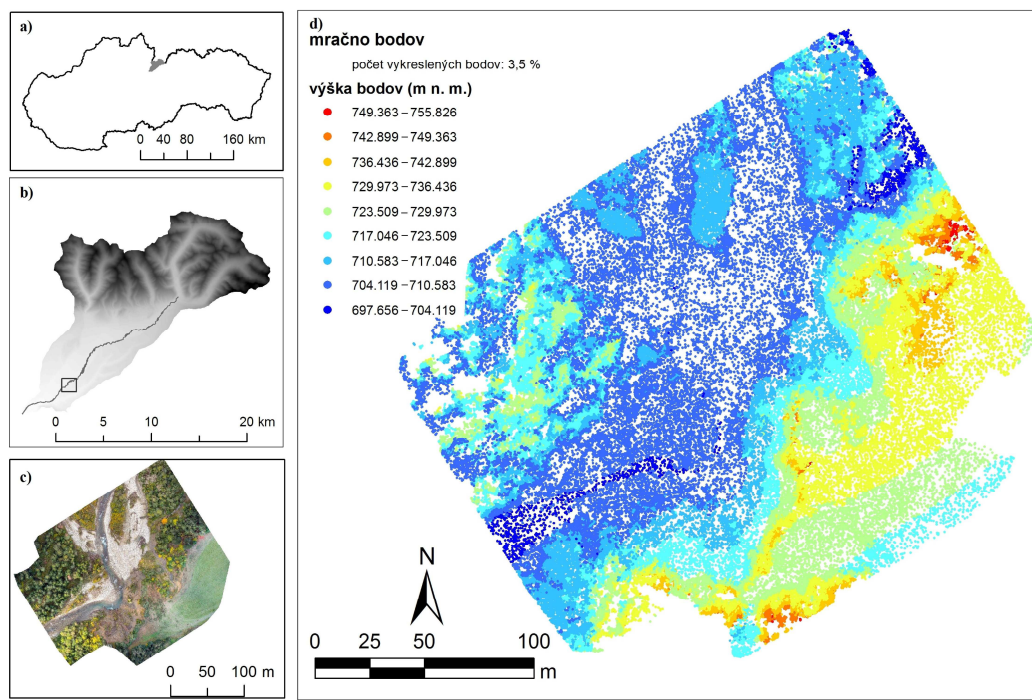

Obr.1. Poloha záujmového územia

$\mathrm{a}$ - lokalizácia povodia rieky Belá, $\mathrm{b}$ - skúmaný riečny úsek $\mathrm{v}$ rámci povodia vodného toku, $\mathrm{c}$ - ortofoto skúmaného územia, $\mathrm{d}$ - mračno bodov získané pomocou UAV fotogrametrie.

\section{ZÍSKAVANIE A SPRACOVANIE DÁT}

Na monitoring rieky Belá bol použitý UAV systém HiSystem Hexakopter XL so šiestimi rotormi a kamerou SONY NEX 6 s objektívom s rozsahom $16-50$ $\mathrm{mm}$. Pri získavaní a spracovaní dát bol dodržaný postup prác podla Rusnáka et al. (2018), ktorý pozostával z nasledujúcich piatich krokov: a) rekognoskácia územia, b) predletová príprava, c) vlastný let, d) kontrola kvality a procesu získavania dát a e) operácia so získanými dátami. Oblast' koryta a jeho okolia boli nalietané v troch polohách. Prvá bola kolmé snímkovanie z výšky $80 \mathrm{~m}$ nad korytom. Druhý typ predstavovalo šikmé snímkovanie telesa zosuvu pod uhlom $30^{\circ}-45^{\circ}$ vo výške 80 , 60 a $50 \mathrm{~m}$ nad terénom. Doplnkovým, tretím snímkovaním v horizontálnej polohe boli nasnímané úseky brehov, ktoré zakrývala vysoká vegetácia. Všetky snímky boli zhotovené v ohniskovej vzdialenosti $16 \mathrm{~mm}$.

Priestorové priradenie modelu sa zabezpečilo pomocou 38 kontrolných bodov (GCP - Ground Control Point) zameraných RTK GPS prístrojom Leica Zeno 5 $\mathrm{s}$ anténou GG03 s presnostou $11 \mathrm{~mm}$. Dáta sa spracovávali v prostredí programu Agisoft PhotoScanTM na štandardnom PC vybavenom procesorom Intel i7 a 32 GB pamät’ovým modulom. PhotoScan umožňuje blokové spracovanie snímok a ich priestorové priradenie (Agisoft PhotoScan 2017). Do spracovania vstupovalo celkovo 1820 snímok a 38, resp. 20 vlícovacích bodov (GCP). Výsledkom spracovania je 3D model, ktorý vytvára virtuálnu reprezentáciu krajiny a je vytvorený $\mathrm{z}$ mračna bodov vysokej hustoty: $100-200$ bodov na $\mathrm{m}^{2}$ (obr. 2). $Z$ nalietaných dát bola vytvorená ortofotomozaika s rozlíšením $2,1 \mathrm{~cm}$. V prvom kroku bolo mračno bodov poloautomaticky klasifikované v softvérovom prostredí Microstation Powerdraft s nadstavbovým modulom Terrasolid - TerraScan, do nasledujúcich piatich tried: vysoká vegetácia (viac ako $5 \mathrm{~m}$ ), stredná vegetácia (od 1,5 $\mathrm{m}$ do $5 \mathrm{~m}$ ), nízka vegetácia (od 0,2 m do 1,5 m), zemský povrch a voda (obr. 2). Výsledkom klasifi- 
kácie bolo generovanie dvoch základných typov mračna bodov a výškových modelov označených ako: 1) DSM - výškový model (mračno bodov), do ktorého vstupovali všetky body mračna (všetky triedy); (obr. 2 čast' a a c) a 2) DTM - digitálny model (mračno bodov) generovaný iba $z$ tried zemský povrch a voda (obr. 2̌̌ast' b a d).
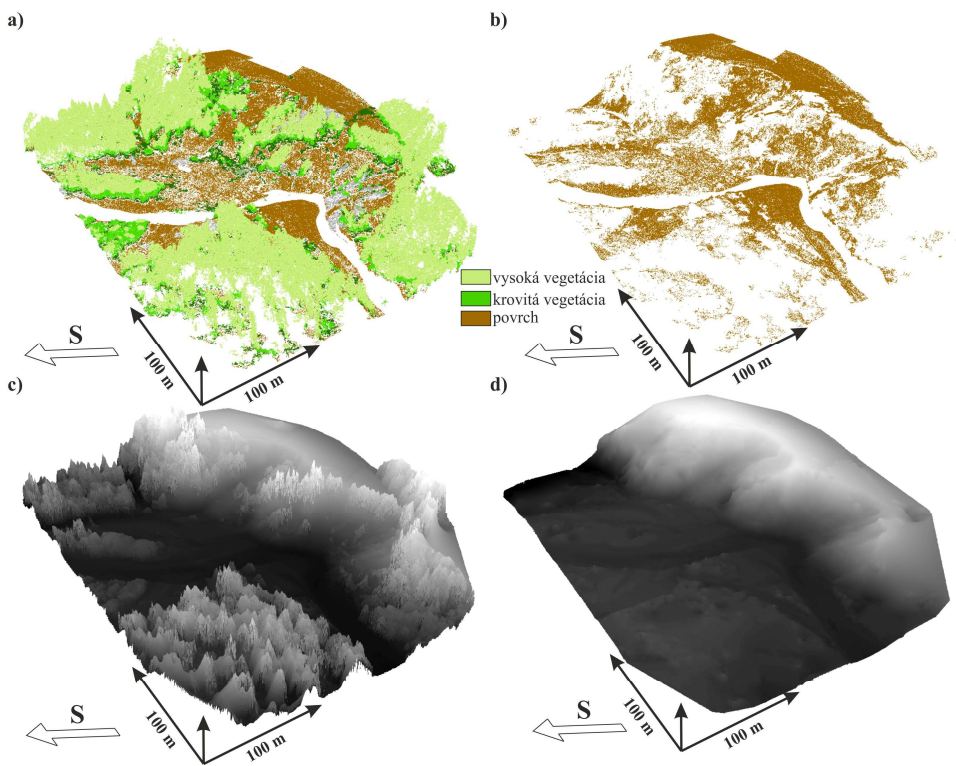

Obr. 2. Vizualizácia mračna bodov

Príklady výsledných formátov a ich 3D vizualizácia vo forme klasifikovaného: a - mračna bodov (hnedá - povrch, odtiene zelenej - vegetácia, modrá - voda), $b$ - mračna bodov triedy povrch, $c$ rastrového modelu povrchu, $\mathrm{d}$ - rastrového modelu terénu.

V druhom kroku bola ortofotosnímka manuálne klasifikovaná do dvojstupňovej databázy, ktorá sa skladala z úrovne geomorfologických foriem (triedy vodná plocha, štrková lavica, ostrov, niva a terasa) a vegetácie (triedy voda, bez vegetácie, nízka vegetácia, krovitá vegetácia, vysoká vegetácia a zhluky dreva a nedefinovaného materiálu).

V d'alšom kroku bola ortofotosnímka generovaná UAV fotogrametriou prevzorkovaná na vel'kosti pixela $5,10,20$ a $50 \mathrm{~cm}$ a pomocou kontrolovanej klasifikácie v softvéri ArcGIS pri použití metódy maximálnej pravdepodobnosti (Maximum Likelihood Classification - MLC) bola klasifikovaná do piatich základných tried: vodná plocha, štrková lavica, vegetácia, zhluky dreva a povrch bez vegetácie. Jednotlivé trénovacie množiny boli manuálne digitalizované do piatich preddefinovaných tried a boli totožné pre všetky rozlíšenia ortofotosnímky. Na odstránenie nesprávnej klasifikácie jednotlivých pixelov a šumu bol na výsledné MLC klasifikácie uplatnený postklasifikačný proces pozostávajúci z filtrácie, zhladenia hraníc a odstránenia malých izolovaných regiónov. Validácia a presnost' klasifikácie boli hodnotené na základe chybovej matice a štatistického indexu zhody - KAPPA indexu. Ako validačná vrstva bola použitá vrstva vzniknutá na základe kombinácie manuálnej vektorizovanej vrstvy geomorfologických foriem a vegetácie, ktorá bola reklasifikovaná na rovnaké triedy ako MLC klasifikácia. 
V poslednom kroku bola hustota bodov hodnotená na základe dvoch manuálne vektorizovaných vrstiev (vrstva geomorfologických foriem a vrstva vegetácie), ktoré slúžili na hodnotenie vplyvu vegetácie na identifikáciu fluviálnych foriem.

\section{VÝSLEDKY}

Presnost' UAV fotogrametrie a manuálne mapovanie

Celková chyba merania vypočítaná softvérom PhotoScan na základe 38 GCP bola 0,336 pixelov, čo predstavuje 0,08 m. Chyba RMSE (Root Mean Square Error), vypočítaná v softvéri PhotoScan, bola po zarovnaní všetkých snímok v smere $x$ súradnice $0,0601 \mathrm{~m}, \mathrm{v}$ smere $y$ súradnice $0,0438 \mathrm{~m}$ a vertikálna chyba bola $0,0295 \mathrm{~m}$. V druhom prípade bol model priradený pomocou $20 \mathrm{GCP}$ a zvyšných 18 slúžilo ako kontrolné body na určenie priestorových chýb. Stredná polohová chyba takto priradeného modelu bola $0,0264 \mathrm{~m}$ a RMSE chyba kontrolných bodov bola $0,0246 \mathrm{~m}$ v osi $x$ a $0,0281 \mathrm{~m}$ v osi $y$ (obr. 3 čast' a). Vertikálna RMSE chyba sa

a)

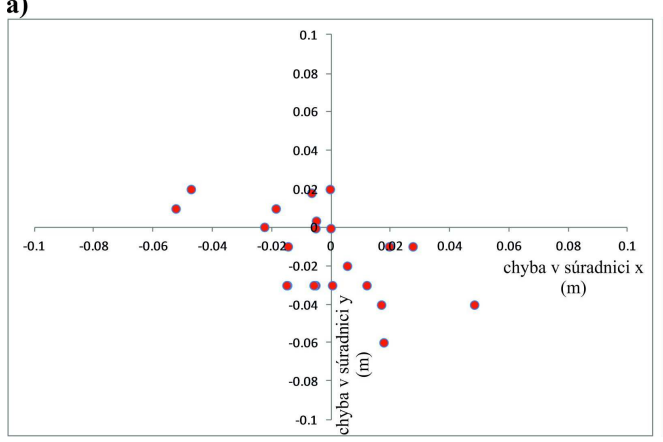

b)

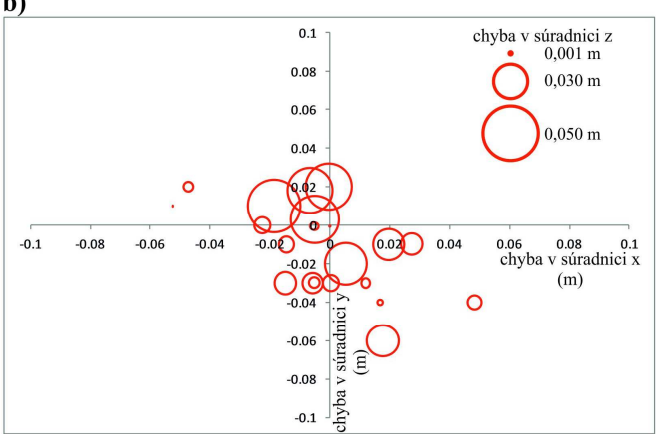

pohybovala na úrovni $0,0284 \mathrm{~m}$ (obr. 3 čast' b).

Obr. 3. Presnosti kontrolných bodov

Chyba kontrolných bodov (18 GCP): a - v smere súradníc $x$ a $y, b$ - chyba jednotlivých kontrolných bodov aj v smere súradnice $z$.

Manuálnou klasifikáciou bolo v študovanom území celkovo vyčlenených 1078 polygónov s minimálnou plochou $0,012 \mathrm{~m}^{2}$, priemernou plochou 49,96 $\mathrm{m}^{2}$ a mediánom $0,432 \mathrm{~m}^{2}$. Ortofotosnímka (obr. 4) poskytuje vysoký rozlišovací detail na identifikáciu drobnej vegetácie pokrývajúcej štrkové lavice a mapovanie zhlukov dreva. Minimálna plocha mapovanej nízkej vegetácie bola $0,012 \mathrm{~m}^{2}$, pričom medián pre celkovo 771 polygónov bol $0,23 \mathrm{~m}^{2}$, čo predstavuje štvorec so stranou $49 \mathrm{~cm}$ a pre najmenšie identifikované plochy trávnatých povrchov štvorec so stranou $10 \mathrm{~cm}$. Mapovanie zhlukov dreva umožňuje identifikovat' jednotlivé kmene stromov, resp. celé zhluky dreva obsahujúce kmene, korene a zvyšky konárov. Celkovo bolo v území identifikovaných 141 zhlukov dreva s celkovým objem $370,31 \mathrm{~m}^{3}$ (vypočítaný na základe sečnej plochy roviny podložia) a s priemerným objemom 2,63 $\mathrm{m}^{3}$. Objem zhlukov dreva pritom predstavuje drevnú hmotu a vzduch medzi jednotlivými kusmi dreva. 

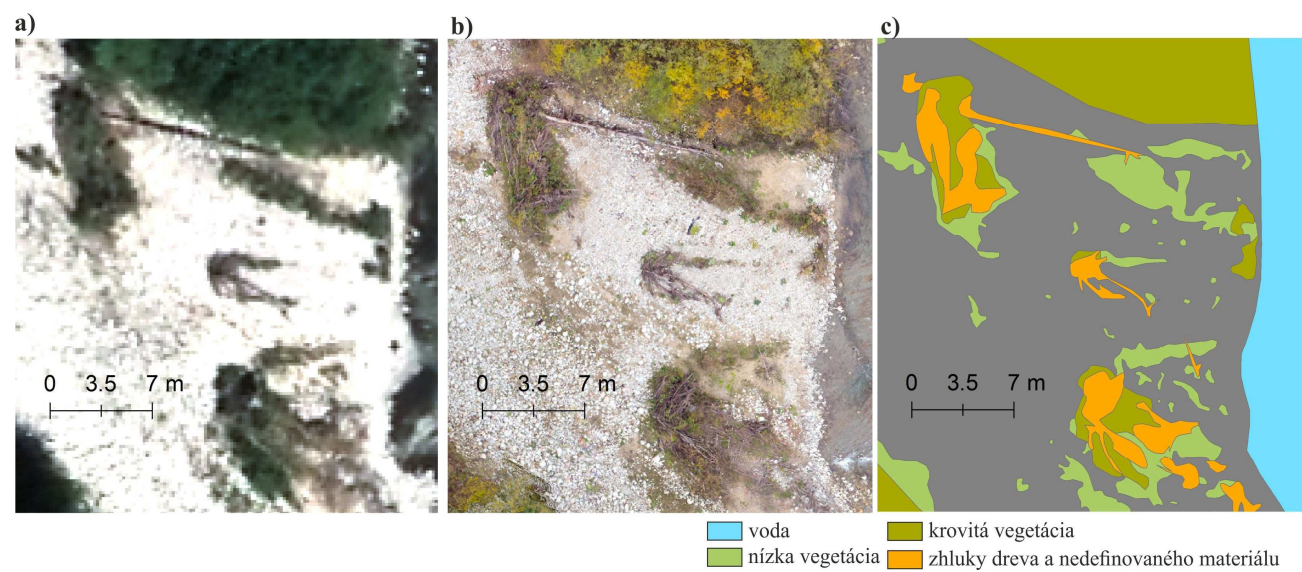

Obr. 4. Porovnanie presnosti UAV ortofotosnímky

a - letecká snímka s rozlíšením $40 \mathrm{~cm}$ (EUROSENSE Slovakia), b - UAV ortofotosnímky $\mathrm{s}$ rozlíšením $5 \mathrm{~cm}, \mathrm{c}$ - výsledná klasifikácia vegetácie.

Legenda: modrá - voda, svetlozelená - nízka vegetácia, tmavozelená - krovitá vegetácia a oranžová - zhluky dreva a nedefinovaného materiálu

\section{Automatická klasifikácia UAV ortofotosnímky}

Ortofotosnímka (s rozlíšením 5, 10, 20 a $50 \mathrm{~cm}$ ) bola klasifikovaná do piatich základných tried objektov (tab. 2) s celkovou presnost'ou $75 \%$ (pre rozlíšenie $5 \mathrm{~cm}), 78 \%(10 \mathrm{~cm}), 77 \%(20 \mathrm{~cm})$ a $74 \%(50 \mathrm{~cm})$. RGB klasifikácia UAV ortofotosnímky je dostatočná na identifikáciu tried vegetácie a štrkových lavíc. Problematická je identifikácia vodnej hladiny, kde vznikajú chyby náklonom vegetácie ponad breh koryta toku (obr. 5) a na okraji plytkých vodných plôch, kde je viditel'ná textúra podložia, resp. dna koryta (triedy klasifikované ako povrch bez vegetácie, resp. štrková lavica). Nízku presnost' vykazuje aj identifikácia povrchov bez vegetácie, predovšetkým trieda zvyškov dreva, ktorá má podobné spektrálne charakteristiky ako trieda vegetácie. Priestorová distribúcia chýb sa viaže predovšetkým na zóny kontaktu voda - štrková lavica (vegetácia) a kontaktu vysokej vegetácie s ostatným typmi tried. Po odstránení triedy zvyšky dreva (tab. 3) sa presnost' klasifikácie zvýšila na 83 \% (KAPPA index 0,633 ) avšak s výrazne podobným rozmiestnením chybných pixelov (obr. 5 čast' d).

Tab. 2. Hodnota štatistického indexu zhody (KAPPA index), celková presnost' automatickej klasifikácie pre ortofotosnímky s rozlíšením $5 \mathrm{~cm}, 10 \mathrm{~cm}, 20 \mathrm{~cm}$ a $50 \mathrm{~cm}$, ako aj pre jednotlivé klasifikované triedy

\begin{tabular}{|c|c|c|c|c|c|}
\hline & & \multicolumn{4}{|c|}{ Rozlíšenie ortofotosnímky } \\
\hline & & $5 \mathrm{~cm}$ & $10 \mathrm{~cm}$ & $20 \mathrm{~cm}$ & $50 \mathrm{~cm}$ \\
\hline & KAPPA index & 0,535 & $\mathbf{0 , 5 8 0}$ & 0,568 & 0,533 \\
\hline & celková presnost' & $75 \%$ & $78 \%$ & $77 \%$ & $74 \%$ \\
\hline \multirow{5}{*}{ Trieda } & vodná plocha & $70 \%$ & $75 \%$ & $82 \%$ & $90 \%$ \\
\hline & štrková lavica & $87 \%$ & $90 \%$ & $91 \%$ & $93 \%$ \\
\hline & vegetácia & $95 \%$ & $95 \%$ & $96 \%$ & $96 \%$ \\
\hline & povrch bez vegetácie & $31 \%$ & $34 \%$ & $33 \%$ & $33 \%$ \\
\hline & zvyšky dreva & $12 \%$ & $14 \%$ & $14 \%$ & $11 \%$ \\
\hline
\end{tabular}


Tab. 3. Chybová matica, hodnota štatistického indexu zhody (KAPPA index) a celková presnost' automatickej klasifikácie pre ortofotosnímku s rozlíšením $5 \mathrm{~cm}$ bez klasifikácie triedy zvyšky dreva

\begin{tabular}{|c|c|c|c|c|c|}
\hline & \multirow{2}{*}{ Trieda } & \multicolumn{4}{|c|}{ Validácia } \\
\hline & & Vodná plocha & Štrková lavica & Vegetácia & Povrch bez vegetácie \\
\hline \multirow{6}{*}{ 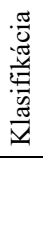 } & vodná plocha & $64 \%$ & $1 \%$ & $31 \%$ & $4 \%$ \\
\hline & štrková lavica & $4 \%$ & $86 \%$ & $9 \%$ & $1 \%$ \\
\hline & vegetácia & $1 \%$ & $2 \%$ & $95 \%$ & $2 \%$ \\
\hline & povrch bez vegetácie & $22 \%$ & $19 \%$ & $30 \%$ & $29 \%$ \\
\hline & & & \multicolumn{2}{|c|}{ celková presnost' } & $83 \%$ \\
\hline & & & \multicolumn{2}{|c|}{ KAPPA index } & 0,633 \\
\hline
\end{tabular}

a)

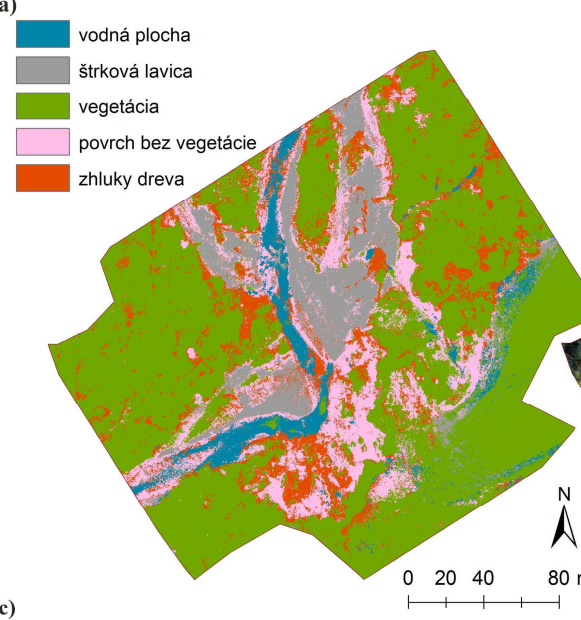

c) b)

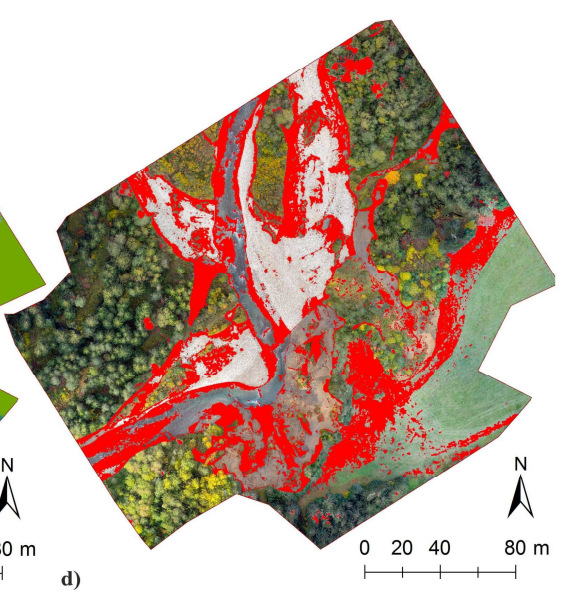
vodná plocha
štrková lavica
vegetácia
plocha bez vegetácie
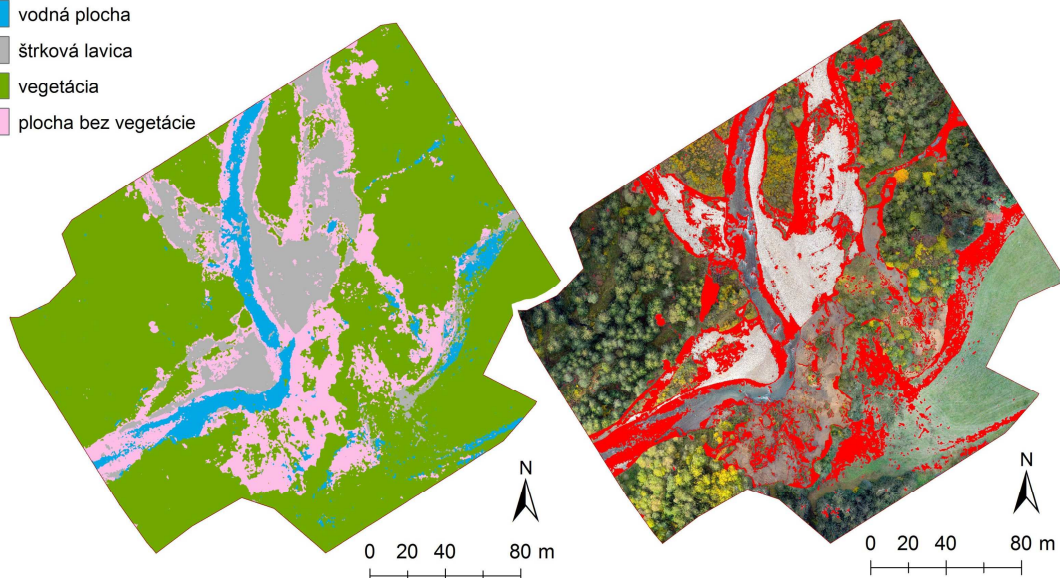

Obr. 5. Výsledná automatická klasifikácia ortofotosnímky s rozlíšením $5 \mathrm{~cm}$

a - klasifikácia ortofotosnímky na 5 tried, b - rozmiestnenie jednotlivých chybných pixelov, c - výsledná klasifikácia po vyradení triedy zhluky dreva, d- rozmiestnenie jednotlivých chýb. 
a)

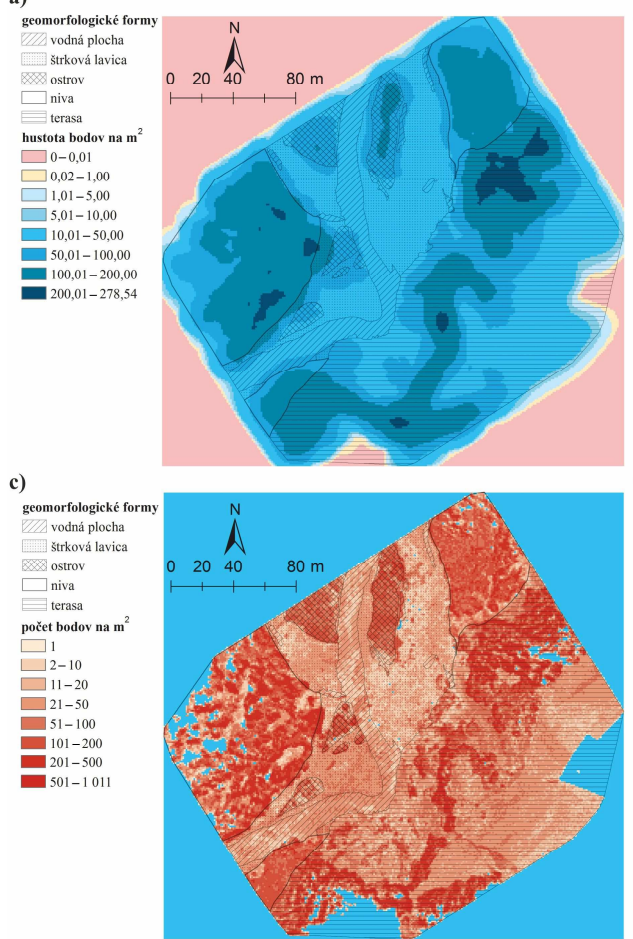

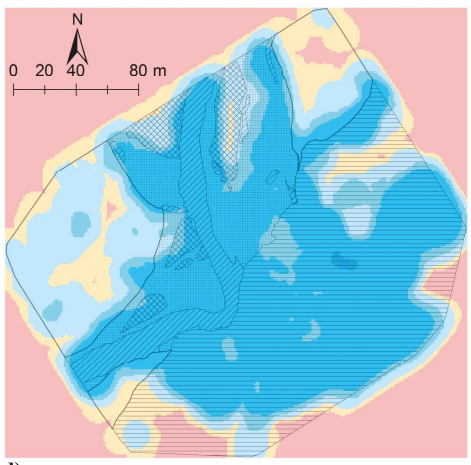

d)

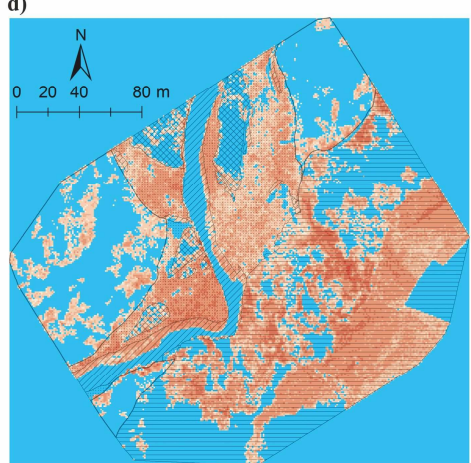

Obr. 6. Množstvo a rozloženie mračna bodov v jednotlivých geomorfologických formách $\mathrm{a}$ - vypočítané ako hustota bodov na $\mathrm{m}^{2}$ pre kruh s polomerom $10 \mathrm{~m}$ pre všetky body, $\mathrm{b}$ - pre body klasifikované ako povrch, $\mathrm{c}$ - znázornenie počtu bodov na $\mathrm{m}^{2}$ pre všetky body mračna, $\mathrm{d}$ - pre body klasifikované ako povrch.

\section{Analýza mračna bodov}

Priemerná hustota mračna bodov na $1 \mathrm{~m}^{2}$ (obr. 6 čast' a a b) po exporte zo softvéru Agisoft pre DSM vypočítaná pre kruh s polomerom $10 \mathrm{~m}$ bola 52,67, pričom maximálna hodnota bola 278,54. Po klasifikácii a selekcii iba bodov zemský povrch a voda poklesla priemerná hustota mračna bodov na hodnotu 8,73 a maximálna hodnota bola 55,67 . Pri hodnotení počtu bodov na $\mathrm{m}^{2}$ tak priemerný počet bodov (obr. 6 čast' $\mathrm{c}$ a d) poklesol z hodnoty 88,18 bodov $/ \mathrm{m}^{2}$ pre DSM (maximálna hodnota 1011 bodov $/ \mathrm{m}^{2}$ ) na 20,91 bodov/ $/ \mathrm{m}^{2}$ pre DTM (maximálna hodnota 158 bodov $/ \mathrm{m}^{2}$ ). Redukcia bodovej hustoty mračna bodov klasifikovaného ako povrch sa prejavuje aj v rozložení jednotlivých početností bodov mračna (obr. 7). Pri neklasifikovanom mračne bodov (DSM) najväčší počet bodov na $\mathrm{m}^{2}$ (obr. 7 čast' c) dosahuje geomorfologická forma niva $\left(131,7 \mathrm{bodov} / \mathrm{m}^{2}\right)$, d’alej nasledujú ostrov a riečna terasa $\left(93,6\right.$ a 92,3 bodov $\left./ \mathrm{m}^{2}\right)$ a najmenej bodov majú triedy vodná plocha a štrková lavica $\left(29,2\right.$ a $\left.36,1 \mathrm{bodov} / \mathrm{m}^{2}\right)$. Pri hodnotení množstva bodov pre jednotlivé typy vegetácie (obr. 7 čast' d) tak má najvýraznejšie zastúpenie vysoká vegetácia $\left(157,3 \mathrm{bodov} / \mathrm{m}^{2}\right)$ a krovitá vegetácia $\left(95,0 \mathrm{bodov} / \mathrm{m}^{2}\right)$. Zvyšné kategórie dosahujú hodnoty od 30 do 50 bodov $/ \mathrm{m}^{2}$. Po selekcii mračna bodov na body reprezentujúce iba povrch (DTM) priemerný počet bodov na štvorcový meter najvýraznejšie klesá v kategórii niva (z 131,7 bodov $/ \mathrm{m}^{2}$ na 2,8 bodov $/ \mathrm{m}^{2}$ ) a ostrovy (z 93,6 bodov/ 
$\mathrm{m}^{2}$ na 4,2 bodov $/ \mathrm{m}^{2}$ ); (obr. 7 čast' c a e), pričom pokles hustoty bodov narastá so zvyšujúcou sa výškou vegetácie (obr. 7 čast' d a f), kde pokleslo množstvo bodov najvýraznejšie $\mathrm{v}$ triede vysoká vegetácia (o 154,2 bodov $/ \mathrm{m}^{2}$ ) a krovitá vegetácia (o 88,4 bodov $/ \mathrm{m}^{2}$ ). Po odfiltrovaní vegetácie $\mathrm{z}$ digitálneho modelu (DTM) bolo najhustejšie bodové pole identifikované pre geomorfologické formy (obr. 7 čast' e) štrková lavica $\left(19,6\right.$ bodov $\left./ \mathrm{m}^{2}\right)$ a terasa $\left(17,9 \mathrm{bodov} / \mathrm{m}^{2}\right)$. Trieda vodná plocha obsahovala 7,9 bodov $/ \mathrm{m}^{2}$ a kategórie obsahujúce vegetačný kryt 4,2 a 2,8 bodov $/ \mathrm{m}^{2}$ (ostrovy a niva). Mračno bodov malo najvyššiu hustotu v rámci tried reprezentujúcich vegetáciu (obr. 7 čast' f) v kategóriách povrch bez vegetácie a povrch s nízkou vegetáciou $\left(24,6\right.$ a 20,5 bodov $\left./ \mathrm{m}^{2}\right)$, pričom ostatné triedy dosahovali výrazne nižšie hustoty bodov.

a)

c)
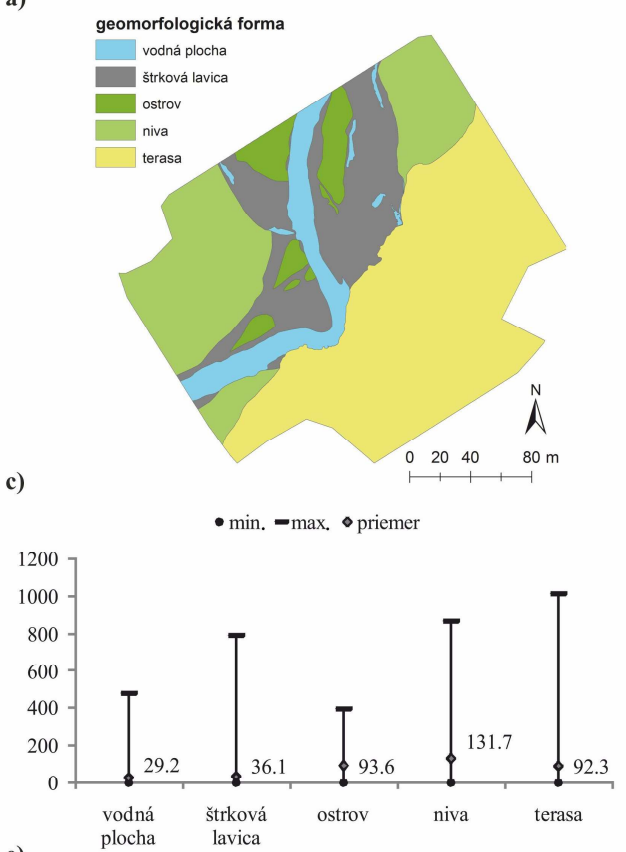

e)

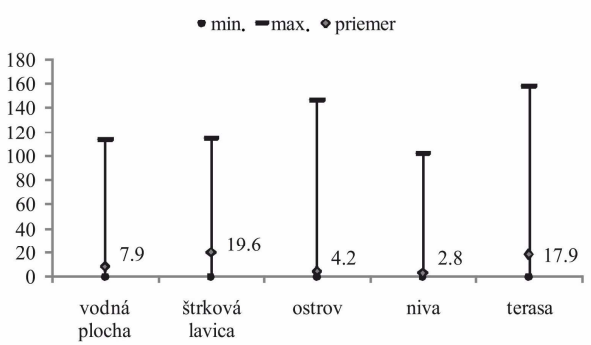

b)

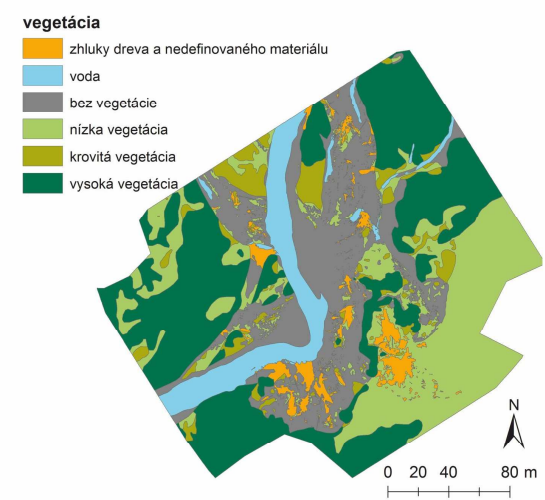

d)
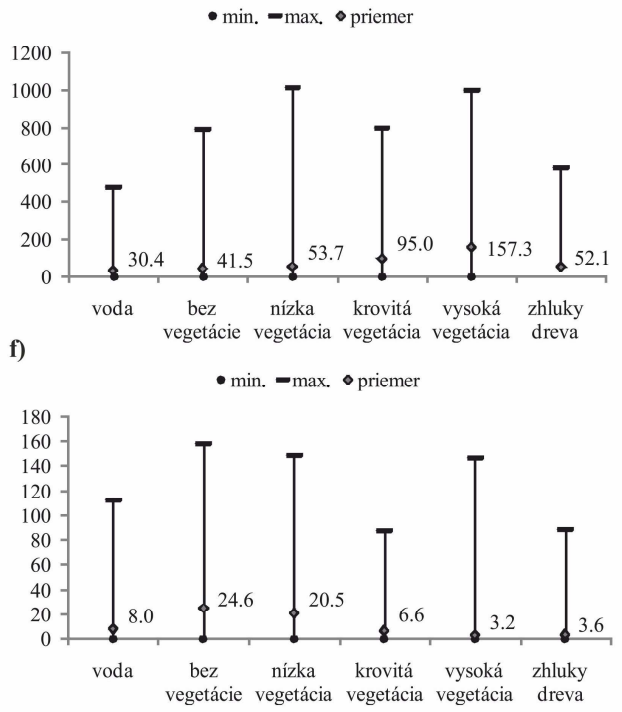

Obr. 7. Štatistika počtu bodov na $\mathrm{m}^{2}$ pre jednotlivé geomorfologické formy a pre jednotlivé triedy vegetácie

$\mathrm{a}$ - triedy geomorfologických foriem, b - vegetácie, $\mathrm{c}-\mathrm{v}$ študovanom území spolu so štatistikou (min, max a priemer) počtu bodov na $\mathrm{m}^{2}$ pre jednotlivé geomorfologické formy: všetky body mračna, e - pre body klasifikované ako povrch, d - pre jednotlivé triedy vegetácie: pre všetky body mračna, $\mathrm{f}-$ pre body klasifikované ako povrch. 


\section{DISKUSIA}

Bezpilotné systémy sú v súčasnosti často využívaným nástrojom na získavanie informácií o krajine vedúcich $\mathrm{k}$ tvorbe digitálnych modelov a iných priestorových informácií, ktoré následne vstupujú do priestorových analýz alebo slúžia na identifikáciu geografických objektov. Napriek tomu, že UAV fotogrametria nedokáže preniknút' vegetáciou ako letecký, resp. pozemný laserový skener, predstavuje presnú, rýchlu a operatívnu technológiu zberu priestorových dát (Turner et al. 2015). Jej výhodou je predovšetkým pomerne nízka obstarávacia cena (Sládek a Rusnák 2013 a Barkóczi et al. 2017)), vysoká operabilita a úspora času oproti klasickým terénnym prácam. Použitím tejto technológie sme získali výslednú ortofotosnímku s rozlíšením $2,1 \mathrm{~cm}$ a digitálny model so strednou polohovou chybou 2,6 $\mathrm{cm}$. Miřijovský a Langhammer (2015) aplikovali UAV technológiu pri výskume tokov na Šumave s výsledným rozlíšením ortofotomozaiky $1,9-2,3 \mathrm{~cm}$ a RMSE chybou $3,7 \mathrm{~cm}$. Flener et al. (2013) poukazujú na rýchlost' získavania údajov pomocou UAV a opisujú kombináciu UAV technológie, batymetrie a pozemného skenovania pri tvorbe komplexného digitálneho modelu vodného toku a jeho okolia s presnost'ou UAV derivovaného modelu 10 až $20 \mathrm{~cm}$. Kombináciu klasických terénnych meraní a UAV technológií prezentujú aj Miřijovský et al. (2015) pri výskume Kenického meandra na rieke Morava v Českej republike.

Výsledná presnost' ortofotosnímky umožňuje spol'ahlivú identifikáciu objektov s rozmermi $10 \mathrm{~cm}$, čo vedie $\mathrm{k}$ presnejšiemu určeniu jednotlivých mikroforiem (povodňové korytá) a spresneniu lokalizácie sukcesie vegetácie a zvyškov dreva (poloha a orientácia dreva $\mathrm{v}$ rámci koryta vytvára prekážky prúdeniu vody). Pri identifikácii objemu zvyškov dreva treba brat' do úvahy pomer medzi jednotlivým podielom vzduchu (air mass) a pevných častí dreva, pre ktorý sa využíva metodika výpočtu indexu hustoty použitého prvýkrát v práci Théveneta et al. (1998) pre rôzne typy zhlukov dreva. Podobne, využitie UAV neumožňuje identifikovat' jednotlivé kusy dreva, ktoré sú pochované štrkovými nánosmi. Automatizácia klasifikácie vedie k zvýšeniu časovej efektivity v porovnaní s manuálnym mapovaním. Mafanya et al. (2017) porovnávajú kontrolovanú a nekontrolovanú klasifikáciu UAV ortofotosnímok založenú na klasifikácii pixelov alebo objektov (objektová klasifikácia). Zdôrazňujú presnost' kontrolovanej klasifikácie a poukazujú na porovnatel'né výsledky klasifikácie založenej na hodnotení objektov a jednotlivých pixelov. Nevýhoda pixelovo orientovaného prístupu spočíva vo výrazne vyššom šume (prejavuje sa efektom ,salt and pepper"). Objektovo orientovaný prístup je výhodnejší na klasifikáciu snímok s vysokým rozlíšením a nízkym počtom spektrálnych pásiem, pričom presnost' závisí od segmentačného algoritmu a sezónne sa meniacich environmentálnych podmienok (Mafanya et al. 2017). UAV snímky s rozlíšením $5 \mathrm{~cm}$ a metódu OBIA využívajú Husson et al. (2016) na automatickú klasifikáciu akvatickej vegetácie a poukazujú na výhody UAV pre operatívne mapovanie, podobne Bertalan et al. (2016) zdôrazňujú perspektívu využitia UAV technológie na identifikáciu vegetácie a systému výmol’ov.

UAV technológie pri použití optických senzorov vytvárajú 3D geometriu obálky povrchov. Na tvorbu digitálneho modelu terénu je preto nevyhnutné získané mračno bodov klasifikovat' a filtrovat', pričom dochádza k výraznému poklesu množstva bodov, ktorý explicitne definuje terén po odstránení bodov vegetácie. V oblastiach s hustou vegetáciou dochádza k výraznému úbytku informácií o výške povrchu (obr. 8). Na identifikovanie jednotlivých foriem je potrebné aj po filtrácii dosiahnut' minimálne množstvo bodov nevyhnutné na identifikáciu hrán objektu. 


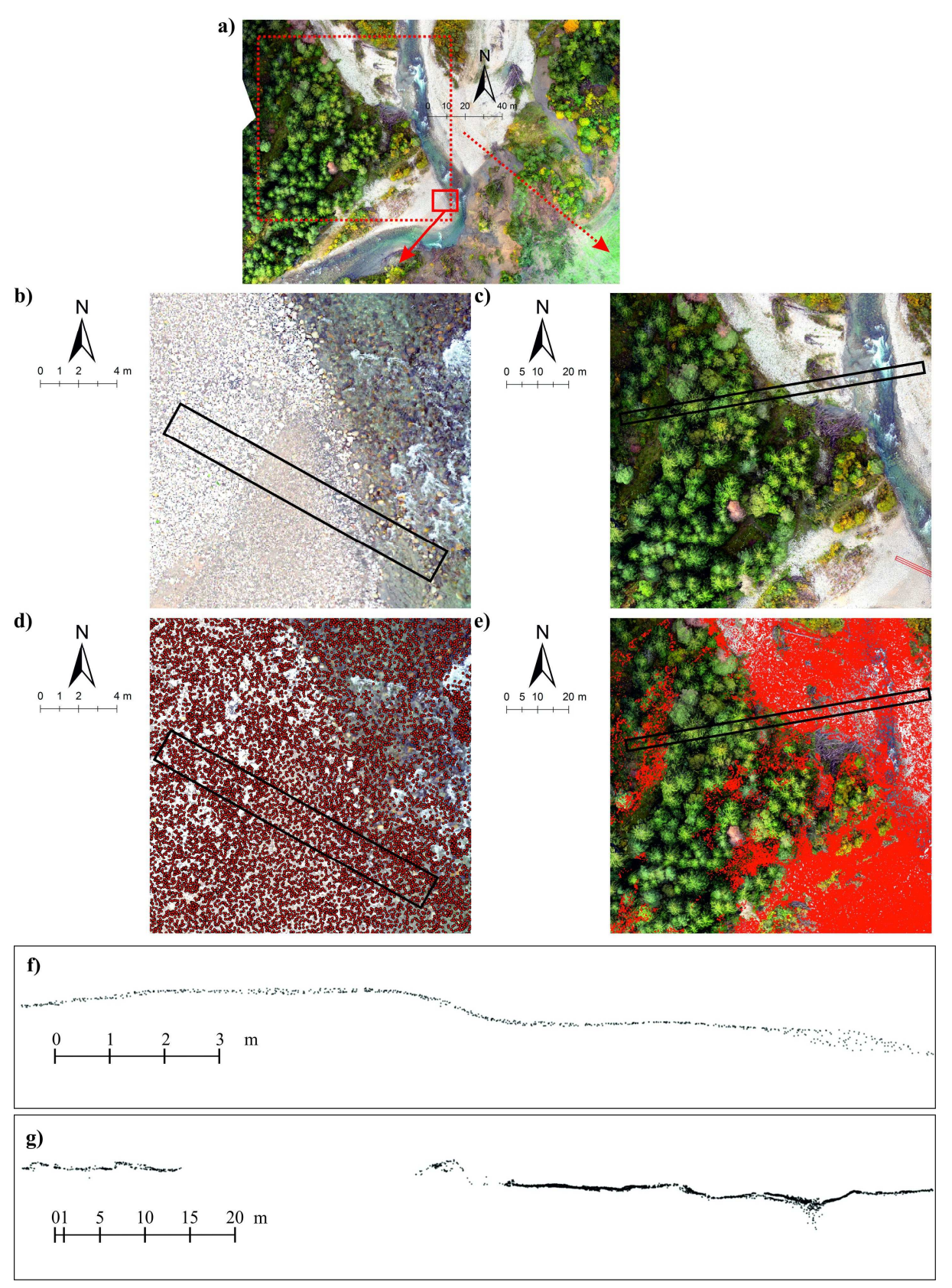

Obr. 8. Rozdiel v hustote mračna bodov zemského povrchu (DTM)

$\mathrm{a}$ - ortofotosnímka študovaného územia, b - oblast’ štrkovej lavice, c - časti nivy s vegetáciou, korytom a bočnou štrkovou lavicou, $\mathrm{d}$ - povrch štrkovej lavice rovnomerne pokrytý mračnom bodov, e - oblasti bez výškovej informácie na nive, $\mathrm{f}$ - body mračna vykreslené na profile reprezentujúceho štrkovú lavicu a čast' nivy, $g$ - body mračna vykreslené na profile reprezentujúceho štrkovú lavicu s chýbajúcimi údajmi a nižšou hustotou bodov na nive. 
Ich množstvo a hustota závisí predovšetkým od vel'kosti skúmaného objektu a jeho hierarchického zaradenia. Napríklad na identifikáciu štrkových lavíc v danom území bola postačujúca hodnota okolo 1 bodu na $\mathrm{m}^{2}$ vypočítaná na základe minimálneho počtu bodov mračna pre jednotlivé manuálne klasifikované polygóny. Pri skúmaní jednotlivých sérií akumulácií na štrkovej lavici je nevyhnuté, aby digitálny model obsahoval niekol'ko bodov na $\mathrm{m}^{2}$ a pri identifikácii granulometrického zloženia to musí byt' niekol'ko bodov na $\mathrm{cm}^{2}$ (Woodget a Austrums 2017). Podobne aj Vericat et al. (2009) poukazujú na UAV technológiu s vysokým rozlíšením $(5-10 \mathrm{~cm})$ ako adekvátnu pre mapovanie riečnych koridorov a využitel'nú ako rutinnú technológiu na monitoring vodného toku, automatickú analýzu vel'kosti zrna substrátu alebo morfologickú analýzu. Niethammer et al. (2012) poukazujú na d’alší problém UAV fotogrametrie, a to je vplyv nízkej vegetácie (malých kríkov a trávy) na presnost' výsledného modelu, ktorú nie je možné odstránit' z fotogrametrického modelu. Hugenholtz et al. (2013) konštatujú, že UAV fotogrametria je využitel'ná najmä pre územia s minimálnou vegetáciou, pričom zdôrazňujú vysoký potenciál UAV fotogrametrie pri sledovaní geodynamických procesov. Klasifikácia mračna bodov zvyšuje presnost' výškového modelu, avšak na druhej strane neumožňuje zachytit' reálny terén a topografiu pod vegetáciou ani po jej odstránení odfiltrovaním z mračna bodov (Rusnák et al. 2016a). V prípade nivy a ostrovov vyskytujúcich sa v sledovanom úseku, riedky zápoj vegetácie umožňuje zachytit' povrch terénu, avšak s výrazne nižšou bodovou hustotou, pričom dochádza $\mathrm{k}$ vytváraniu zhlukov bodov, kde optický snímač zachytil zemský povrch. V porovnaní s metódami klasického terénneho mapovania, ktoré vytvára iba schématizovaný model študovaného územia, Miřijovský a Langhammer (2015) rovnako zdôrazňujú presnost' a spol'ahlivost' technológie pri využití vo fluviálno-geomorfologickom výskume.

\section{ZÁVER}

UAV predstavujú rýchlo sa rozvíjajúcu platformu pre zber priestorových dát, monitoring a mapovanie územia vo vel'kej mierke. Aplikácia počítačových algoritmov prináša oproti klasickým fotogrametrickým metódam vyššiu mieru automatizácie, čo vedie $\mathrm{k}$ ich l'ahšiemu použitiu a využitiu v širšom spektre vedeckých oblastí. Na druhej strane, zjednodušené a užívatel'sky nekomplikované prostredie vedie k využívaniu technológie ako ,čiernej skrinky“, kde je dôležité iba naplnenie dátami a výsledky častokrát nie sú spätne verifikovatel'né. Bezpilotné prostriedky a UAV fotogrametria poskytujú presné dáta s vysokým rozlíšením, s prijatel'nou nadobúdacou cenou a $\mathrm{s}$ časovo nenáročným zberom dát. Výsledkom spracovania je kvalitný 3D model študovaného územia s celkovou chybou geometrie $26,42 \mathrm{~mm}$ a RMSE chybou $24,59 \mathrm{~mm}$ v smere $x ; 28,12 \mathrm{~mm}$ v smere $y$ a 28,36 $\mathrm{mm}$ v smere $z$. Limitom technológie je tvorba obálky povrchu, ktorý neumožňuje rekonštrukciu povrchu pod hustou vegetáciou. Pre tvorbu digitálneho modelu terénu je preto nevyhnutné získané mračno bodov klasifikovat' a filtrovat', pričom dochádza k výraznému poklesu množstva bodov najmä po odstránení bodov vegetácie. Redukcia mračna bodov je tak najvýraznejšia predovšetkým v oblasti nivy a ostrovov, kde zachytáva iba väčšie fluviálne formy reliéfu, a preto je pre d'alšie priestorové analýzy nevyhnutné zhodnotenie kvality takto získaného výškového modelu povrchu terénu. 
Príspevok vznikol s podporou Vedeckej grantovej agentúry Ministerstva školstva, vedy, výskumu a športu Slovenskej republiky a Slovenskej akadémie vied (VEGA) ćíslo 2/0098/18. Letecké práce boli realizované v spolupráci s GEOTECH Bratislava, s. r. o.

\section{LITERATÚRA}

AGISOFT PHOTOSCAN (2017). User Manual. Professional Edition, Version 1.3. [Online]. Dostupné na: http://www.agisoft.com/pdf/photoscan-pro 13 en.pdf [cit: 1502-2017].

ANSTEAD, L., BARABAS, D. (2013). Hydromorfologický prieskum Váhu ako nástroj pre manažment vodných tokov na Slovensku. Geografický časopis, 65, 61-81.

BARKÓCZI, N., BERTALAN, L., SZABÓ, G., DEÁK, M., KARI, S., CSENGE VIZI, J., ZAGORẢCZ, M., SIK, A., RIEDEL, M., KOHÁN, B., MÉSZẢROS, J., SZALAI, Z., SZABÓ, O., NAGY, B. (2017). Examples from the boundaries of geographic survey: architecture and flood modelling. In Casagrande, G., Sik, A., Szabó, G., eds. Small flying drones. Dordrecht (Springer), pp. 127-156.

BERTALAN, L., TÚRI, Z., SZABÓ, G. (2016). UAS photogrammetry and object-based image analysis (GEOBIA): erosion monitoring at the Kazár badland, Hungary. Acta Geographica Debrecina. Landscape and Environment, 10, 169-178.

BLIŠŤAN, P., KOVANIČ, L., PALKOVÁ, J., ZELIZNÁKOVÁ, V. (2016a). Overenie použitel'nosti nízkonákladovej fotogrametrie UAV v kontexte banskomeračskej legislatívy Slovenskej republiky. Kartografické listy, 24, 3-11.

BLIŠTAN, P., KOVANIČ, L., ZELIZNÁKOVÄ, V., PALKOVÁ, J. (2016b). Using UAV photogrammetry to document rock outcrops. Acta Montanistica Slovaca, 21, 154-161.

BLIŠŤANOVÁ, M., BLAŽEK, J., BLIŠŤAN, P., REITŠPÍS, J., HAVAJ, P. (2016). Support for protection of the large object using UAVs. Advances in Military Technology, 11, 227-237.

BLIŠŢANOVÁ, M., BLIŠŤAN, P. BLAŽEK, J. (2015). Mapping of surface objects and phenomena using Unmanned Aerial Vehicle for the purposes of crisis. SGEM2015 Conference Proceedings, Book 5, Vol. 1, June 18-24, Sofia, pp. 491-500. [Online]. Dostupné na: https://sgemworld.at/sgemlib/spip.php?article6317 [cit: 25-05-2017].

BRŮNA, V., PACINA, J., PACINA, J., VAJSOVA, E. (2014). Modelling the extinct landscape and settlement for preservation of cultural heritage. Citta e Storia, 9, 131-153.

DIETRICH, J. T. (2016). Riverscape mapping with helicopter-based structure-from-motion photogrammetry. Geomorphology, 252, 144-157.

DUNFORD, R., MICHEL, K., GAGNAGE, M., PIÉGAY, H., TRÉMÉLO, M. L. (2009). Potential and constraints of unmanned aerial vehicle technology for the characterization of Mediterranean riparian forest. International Journal of Remote Sensing, 30, 49154935.

FLENER, C., VAAJA, M., JAAKKOLA, A., KROOKS, A., KAARTINEN, H., KUKKO, A., KASVI, E., HYYPPÄ, H., ALHO, P. (2013). Seamless mapping of river channels at high resolution using mobile LiDAR and UAV-photography. Remote Sensing, 5, 63826407.

FONSTAD, M. A., DIETRICH, J. T., COURVILle, B. C., JENSEN, J. L., CARBONNEAU, P. E. (2013). Topographic structure from motion: a new development in photogrammetric measurement. Earth Surface Processes and Landforms, 38, 421-430.

FRANDOFER, M., LEHOTSKÝ, M. (2013). Stupňovitá štruktúra dna koryta vodného toku s výrazným pozdížnym sklonom (na príklade horného úseku rieky Topl'a). Geografický časopis, 65, 141-159.

FRANDOFER, M., LEHOTSKÝ, M. (2014). Morfologicko-sedimentová diferenciácia horského vodného toku a jeho odozva na povodňové udalosti. Geomorphologia Slovaca and Bohemica, 14(1), 5-86. 
GALLAY, M., ECK, CH., ZGRAGGEN, C., KAŇUK, J., DVORNÝ, E. (2016a). High resolution airborne laser scanning and hyperspectral imaging with a small UAV platform. The International Archives of the Photogrammetry, Remote Sensing and Spatial Information Sciences, 16-B1, 823-827.

GALLAY, M., HOCHMUTH, Z., KANUK, J., HOFIERKA, J. (2016b). Geomorphometric analysis of cave ceiling channels mapped with 3D terrestrial laser scanning. Hydrolology and Earth System Sciences, 20, 1827-1849.

GALLAY, M., KAŇUK, J., HOCHMUTH, Z., MENEELY, J., HOFIERKA, J., SEDLÁK, V. (2015). Large-scale and high-resolution 3-D cave mapping by terrestrial laser scanning: a case study of the Domica Cave, Slovakia. International Journal of Speleology, 44, 277-291.

HANZL, V., PLÁNKA, L. (1992). Letecké snímkování z malých výšek s využitím dálkově_ř́zených nosičůa neměřických kamer. Vojenský topografický obzor. Sborník topogräfické služby, $1,11-12$.

HARWIN, S., LUCIEER, A. (2012). Assessing the accuracy of georeferenced point clouds produced via multi-view stereopsis from unmanned aerial vehicle (UAV) imagery. $R e$ mote Sensing, 4, 1573-1599.

HERVOUET, A., DUNFORD, R., PIÉGAY, H., BELlETTI, B., TRÉMÉLO, M. L. (2011). Analysis of post-flood recruitment patterns in braided-channel rivers at multiple scales based on an image series collected by unmanned aerial vehicles, ultralight aerial vehicles, and satellites. GIScience \& Remote Sensing, 48, 50-73.

HUGENHOLTZ, CH. H., WHITEHEAD, K., BROWN, O. W., BARCHYN, T. E., MOORMAN, B. J., LECLAIR, A., RIDDELL, K., HAMILTON, T. (2013). Geomorphological mapping with a small unmanned aircraft system (sUAS): feature detection and accuracy assessment of a photogrammetrically-derived digital terrain model. Geomorphology, 194, 16-24.

HUSSON, E., ECKE, F., REESE, H. (2016). Comparison of manual mapping and automated object-based image analysis of non-submerged aquatic vegetation from veryhigh-resolution UAS Images. Remote Sensing, 8, 724-742.

JAIN, V., TANDOM, S. K., SINHA, R. (2012). Application of modern geomorphic concepts for understanding the spatio-temporal complexity of the large Ganga river dispersal system. Current Science, 103, 1300-1319.

JAMES, M. R., ROBSON, S. (2012). Straightforward reconstruction of 3D surfaces and topography with a camera: accuracy and geoscience application. Journal of Geophysical Research, 117, 1-17.

KIDOVÁ, A., LEHOTSKÝ, M., RUSNÁK, M. (2016). Spatio-temporal geomorphic diversity in the braided-wandering Belá River, Slovak Carpathians, as a response to modern flood periods and environmental changes. Geomorphology, 272, 137-149.

KELCEY, J., LUCIEER, A. (2012). Sensor correction of a 6-Band multispectral imaging sensor for UAV remote sensing. Remote Sensing, 4, 1462-1493.

KOLEJKA, J. (1987). Stav a metody dálkového průzkumu př́rodních a antropogenních krajinných struktur na Geografickém ústavu ČSAV v Brne. Zprávy $G G U^{\prime} \check{C} S A V, 24(1)$, 17-30.

KOLEJKA, J., PETCH, J. (1989). Geografické vyhodnocení digitalizovaných leteckých snímků vodních objektů. Sbornik ČSGS, 94, 241-248.

KRŠLÁK, B., BLIŠTAN, P., PAULIKOVÁ, A., PUŠKÁROVÁ, P., KOVANIČ, L., PALKOVÁ, J., ZELIZNÁKOVÁ, V. (2016). Use of low-cost UAV photogrammetry to analyze the accuracy of a digital elevation model in a case study. Measurement, 91, 276-287.

LANGHAMMER, J., LENDZIOCH, T., MIŘIJOVSKÝ, J., HARTVICH, F. (2017). UAVbased optical granulometry as tool for detecting changes in structure of flood depositions. Remote Sensing, 9, 240.

LEHOTSKÝ, M., LACIKA, J. (2007). Typy segmentov dolinovo-riečnych systémov s vel'vysočinovou zdrojovou zónou: príklad Tatier. Geomorphologia Slovaca et Bohemica, 1, 27-35. 
LEJOT, J., DELACOURT, C., PIÉGAY, H., FOURNIER, T., TRÉMÉLO, M. L., ALLEMAND, P. (2007). Very high spatial resolution imagery for channel bathymetry and topography from an unmanned mapping controlled platform. Earth Surface Processes and Landforms, 32, 1705-1725.

MAFANYA, M., TSELE, P., BOTAI, J., MANYAMA, P., SWART, B., MONATE, T. (2017). Evaluating pixel and object based image classification techniques for mapping plant invasions from UAV derived aerial imagery: Harrisia pomanensis as a case study. ISPRS Journal of Photogrammetry and Remote Sensing, 129, 1-11.

MEDVEĎOVÁ, A., PROKEŠOVÁ, R., KRÁTKA, E. (2007). Morfológia bystrinného toku - príklad potoka Vôdka. Geomorphologia Slovaca et Bohemica, 2, 25-35.

MICHELETTI, N., CHANDLER, J. H., LANE, S. N. (2015). Structure from motion (SFM) photogrammetry. In Clarke, L. E., Nield, J. M., eds. Geomorphological techniques. London (British Society for Geomorphology), pp. 1-12.

MIKITA, T., JANATA, P., SUROVÝ, P. (2016). Forest stand inventory based on combined aerial and terrestrial close-range photogrammetry. Forests, 7, 165-179.

MIŘIJOVSKÝ, J. (2013). Bezpilotní systémy - sběr dat a využití ve fotogrammetrii. Olomouc (UP Publishing).

MIŘIJOVSKÝ, J., LANGHAMMER, J. (2015). Multitemporal montoring of the morphodynamics of a mid-mountain stream using UAS photogrammetry. Remote Sensing, 7, 8586-8609.

MIŘIJOVSKÝ, J., MICHALKOVÁ, M. Š., PETYNIAK, O., MÁČKA, Z., TRIZNA, M. (2015). Spatiotemporal evolution of a unique preserved meandering system in Central Europe - the Morava River near Litovel. Catena, 127, 300-311.

MIŘIJOVSKÝ, J., PECHANEC, V., BURIAN, J. (2012). Využití bezpilotního modelu PIXY při snímkování krajiny. Informace ČGS, 31, 11-17.

MIŘIJOVSKÝ, J., VÁVRA, A. (2012). UAV photogrametry in fluvial geomorphology. SGEM2012 Conference Proceedings, 2, June 17-23, Sofia, pp. 909-916, [Online]. Dostupné na: https://sgemworld.at/sgemlib/spip.php?article2043 [cit: 15-02-2017]. DOI: 10.5593/SGEM2012/S08.V2009.

MÜLLEROVÁ, J., BRŮNA, J., DVOŘ́K, P., BARTALOŠ, T., VÍTKOVÁ, M. (2016). Does the data resolution/origin matter? Satellite, airborne and UAV imagery to tackle plant invasions. The International Archives of the Photogrammetry, Remote Sensing and Spatial Information Sciences, 41-B7, 903-908.

MÜLlEROVÁ, J., BARTALOŠ, T., BRŮNA, J., DVOŘÁK, P., VÍTKOVÁ, M. (2017). Unmanned aircraft in nature conservation: an example from plant invasions. International Journal of Remote Sensing, 38, 2177-2198.

NEITZEL, F., KLONOWSKI, J. (2011). Mobile 3D mapping with a low-cost UAV system. The International Archives of the Photogrammetry, Remote Sensing and Spatial Information Sciences, 38-C22, 39-44.

NIETHAMMER, U., JAMES, M. R., ROTHMUND, S., TRAVELLETTI, J., JOSWIG, M. (2012). UAV-based remote sensing of the Super-Sauze landslide: evaluation and results. Engineering Geology, 128, 2-11.

NOVOTNÝ, J. CEBECAUEROVÁ, M. (2016). Vybrané aspekty transformácie fluviálneho systému rieky Váh v 20. storočí. Geografický časopis, 68, 73-92.

NOVOTNÝ, J., LEHOTSKÝ, M., GRESKOVÁ, A. (2007). Súčasný morfologický vývoj medzihrádzového priestoru (Dunaj, Bratislava). Geomorphologia Slovaca et Bohemica, 2, $72-78$.

PACINA, J. (2015). Geodetic surveying as a tool for discovering the prehistoric settlement in Sudan (the 6th Nile cataract). Geoinformatics FCE CTU, 14, 47-64.

PACINA, J., HOLÁ, M. (2014). Settlement identification in abandoned borderland. SGEM2014 Conference Proceedings, Book 2, Vol. 1, June 19-25, Sofia, DOI: 10.5593/ SGEM2014/B21/S8.099

PACINA, J., POPELKA, J., TOBISCH, M. (2016). Small format aerial photography used for settlement identification in over flooded area. Interdisciplinarity in theory and practice, 10, 258-263. 
PACINA, J., SLÁDEK, J. (2015). Observing landscape changes using distant methods. The Civil Engineering Journal, 1, 1-11.

PIŠÚT, P. (1995). Meandrovanie Dunaja pri Bodíkoch pred zmenou charakteru riečiska v 18. storočí. Geografický časopis, 47, 285-298.

PIŠÚT, P. (2002). Channel evolution of the pre-channelized Danube River in Bratislava, Slovakia (1712 - 1886). Earth Surface Processes and Landforms, 27, 369-390.

PIŠÚT, P. (2006). Evolution of meandering Lower Morava river (West Slovakia) during the first half of 20th century. Geomorphologia Slovaca et Bohemica, 6, 55-68

PIŠÚT, P. (2008). Endangerment of the village Čunovo (Slovakia) by lateral erosion of the Danube River in the 18th century. Moravian Geographical Reports, 16, 33-44.

PIŠÚT, P., TOMČÍKOVA, I. (2008). Rekonštrukcia vývoja rieky Smrečinaky v jej odozvovej zóne podl'a historických máp. Geographia Cassoviensis, 1, 122-127.

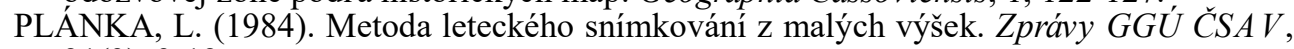
21(3), 3-12.

PLÁNKA, L. (1987). The use of radio-controlled aeromodels for photography with the view of remote sensing of the Earth. In United Nations Training Course „Remote Sensing Applications to Geological Sciences", October 5 - 24, 1987, Dresden, Veröffentlichungen des Zentralinstituts für Physik der Erde. Potsdam (ZIPE), pp. 58-69.

PLÁNKA, L. (2014). Počátky snímkovaní RC-modely letadel v Československu. In Praktické využití GIS v lesníctve a zemédelství, Brno, 27. - 28.2.2014. [Online]. Dostupné na: http://lfgm.fsv.cvut.cz/telc/2014/texty/Planka.pdf [cit:17-05-2017].

PLÁNKA, L., KIRCHNER, K., TRNKA, J. (1983). Snímkování radiem rízeným modelem letadla v oblasti navrhované státní př́rodní rezervace Babín. Zpracováno pro Správu CHKO Žd'árské vrchy, Archiv GGÚ ČSAV, Brno, 12 str.

RUSNÁK, M., BUŠA, J., SLÁDEK, J., GREIF, V. (2016a). Suitability of digital elevation models generated by UAV photogrammetry for slope stability assessment (case study of landslide in Svätý Anton, Slovakia). Acta Scientiarum Polonorum, Formatio Circumiectus, $15,439-450$.

RUSNÁK, M., LEHOTSKÝ, M. (2014). Time-focused investigation of river channel morphological changes due to extreme floods. Zeitschrift für Geomorphologie, 58, 251-266.

RUSNÁK, M., LEHOTSKÝ, M., KIDOVÁ, A. (2016b). Channel migration inferred from aerial photographs, its timing and environmental consequences as the response to present-day floods (the case study: the meandering Topl'a River, Slovak Carpathians). Moravian Geographical Report, 24(3), 32-43.

RUSNÁK, M., SLÁDEK, J., KIDOVÁ, A., LEHOTSKÝ, M. (2018). Template for highresolution river landscape mapping using UAV technology. Measurement, 115, 139151.

SLÁDEK, J., RUSNÁK, M. (2013). Nízkonákladové mikro-UAV techológie v geografii (nová metóda zberu priestorových dát). Geografický časopis, 65, 269-285.

SVOBODOVÁ, J., MIRIJOVSKÝ, J., KILIANOVÁ, H. (2012). The peculiarities of the digital surface model creation from the data acquired by small format photography. SGEM2012 Conference Proceedings, Vol. 3, June 17-23, Sofia, 417-424. [Online]. Dostupné na: https://sgemworld.at/sgemlib/spip.php?article2136 [cit:17-05-2017]. DOI: 10.5593/SGEM2012/S11.V3010

STUCHLÍK, R., STACHOŇ, R., LÁSKA, K., KUBÍČEK, P. (2015). Unmanned aerial vehicle - efficient mapping tool available for recent research in polar regions. Czech polar reports, 5, 210-221.

SZABÓ, G., BERTALAN, L., BARKÓCZI, N., KOVÁCS, Z., BURAI, P., LÉNÁRT, C. (2017). Zooming on aerial survey. In Casagrande, G., Sik, A., Szabó, G., eds. Small flying drones. Dordrecht (Springer), pp. 91-126.

TAMMINGA, A. D., EATON, B. C., HUGENHOLTZ, CH. H. (2015). UAS-based remote sensing of fluvial change following an extreme flood event. Earth Surface Processes and Landforms, 40, 1464-1476. 
THÉVENET, A., CITTERIO, A., PIÉGAY, H. (1998). A new methodology for the assessment of large woody debris accumulations on highly modified rivers (example of two French piedmont rivers). Regulated Rivers: Research \& Management, 14, 467-483.

TOMAŠTIK, J., MOKROS, M., SALOŇ, Š., CHUDÝ, F., TUNÁK, D. (2017). Accuracy of photogrammetric UAV-based point clouds under conditions of partially-open forest canopy. Forests, 8, 151-167.

TOMČÍKOVA, I. (2007). Hierarchická klasifikácia riečnej krajiny na príklade rieky Smrečianka. Geographia Cassoviensis, 1, 193-196.

TURNER, D., LUCIEER, A., de JONG, M. (2015). Time series analysis of landslide dynamics using an unmanned aerial vehicle (UAV). Remote Sensing, 7, 1736-1757.

ULLMAN, S. (1979). The interpretation of visual motion. Cambridge (MIT Press).

VERICAT, D., BRASINGTON, J., WHEATON, J., COWIE, M. (2009). Accuracy assessment of aerial photographs acquired using lighter-than-air-blimps: low-cost tools for mapping river corridors. River Research and Applications, 25, 985-1000.

WESTOBY, M. J., BRASINGTON, J., GLASSER, N. F., HAMBREY, M. J., REYNOLDS, J. M. (2012). "Structure from motion" photogrammetry: a low-cost, effective tool for geoscience applications. Geomorphology, 179, 300-314.

WOODGET, A. S., AUSTRUMS, R. (2017). Subaerial gravel size measurement using topographic data derived from a UAV-SfM approach. Earth Surface Processes and Landforms, 42, 1434-1443.

\section{Miloš Rus nák, Ján Sláde k, Anna Ki dová}

\section{USING UAV TECHNOLOGY FOR LANDSCAPE CLASSIFICATION AND MAPPING IN FLUVIAL GEOMORPHOLOGY}

The main aim of this paper is to present the possibilities of UAV technology (Unmanned Aerial Vehicle) for the identification and mapping of fluvial landforms and analysis of the point cloud density after vegetation filtration in fluvial geomorphic research. The accuracy and density of classified point cloud and orthophotomosaics in riparian zone within several geomorphic landforms and different vegetation covers was assessed. UAV technology enables to apply a new and perspective method for spatial data collection, monitoring and mapping in large scale research. For monitoring of the selected Belá River reach the UAV system from the HiSystem company was used: HEXAKOPTER XL with 6 rotors and the Sony NEX 6 camera with 16-50 mm lens. Spatial referencing was performed with 38 control points (GCP - Ground Control Point) targeted by RTK GPS Leica Zeno 5 with a GG03 antenna and an accuracy of $11 \mathrm{~mm}$. For data processing Agisoft PhotoScan software was used, which operates on the principle of the SfM algorithm. The advantages of this method is the high level of automation. UAV photogrammetry provides accurate data with a high resolution, affordable acquisition cost and represent a less time-consuming data collection technique. Total geometry error was $80 \mathrm{~mm}$ and the RMSE (root mean square error), after aligning all the images, was $60.121 \mathrm{~mm}$ ( $x$ coordinate), $43.7584 \mathrm{~mm}$ ( $y$ coordinate) and $29.46 \mathrm{~mm}$ ( $z$ coordinate). The density of 3D point clouds was 240 points per $\mathrm{m}^{2}$ and an orthophotomosaic was generated with a pixel resolution of $0.021 \mathrm{~m}$. Proficient automated classification (supervised Maximum Likelihood Classification) was achieved for the "vegetation" and "gravel bar" classes and the lower accuracy of water class due to vegetation class cover overhanging the bank line, visible bedrock under the water level classified in the bare-surface class and the graveled channel bed in the gravel-bar class was observed. The SfM algorithm creates an envelope surface model with vegetation cover and for that the resulting point cloud was semiautomatically classified in the software Terrasolid - Terrascan (Microstation), in the following five classes: high vegetation (over $5 \mathrm{~m}$ ), medium vegetation (from $1.5 \mathrm{~m}$ to $5 \mathrm{~m}$ ), small vegetation (from $02 \mathrm{~m}$ to $1.5 \mathrm{~m}$ ), topographic surface and water surface. The classification of point clouds increases the accuracy elevation mod$\mathrm{el}$, but on the other hand, does not capture the real terrain and topography under the vegeta- 
tion. The sparse vegetation canopy allows the capture of the surface of the ground, but with a significantly lower point density and therefore it is necessary to evaluate the quality and thus obtained elevation model. The average density of points per square meter is the most significant drop in the category of the floodplain (from 131.7 points per $\mathrm{m}^{2}$ to 2.8 points per $\mathrm{m}^{2}$ ), wherein the density of points is increased with the increasing height of the vegetation. In the areas with dense vegetation there is an obvious significant loss of information of the surface height. 